\title{
Model Pengembangan Manajemen Bisnis Pondok Modern Darussalam Gontor Ponorogo, Indonesia
}

\author{
Suharto $^{1}$ dan Muhammad Iqbal Fasa ${ }^{2}$ \\ IProffesor at Islamic State University of Lampung \\ E-mail : suhartoradenintan@gmail.com \\ 2Doctor Candidate of Islamic Economics at Islamic State University of \\ Yogyakarta \\ E-mail: muhammadiqbalfasa@ymail.com
}

\begin{abstract}
This paper tries to offer business development model Pondok Modern Darussalam Gontor Ponorogo Indonesia. Pondok Modern Darussalam Gontor success in managing 30 business units formed its own characteristic. As for the characteristics of the business unit management Pondok Modern Darussalam Gontor is: Planning based on the value of cottage; Organizing based on regeneration; Transformative collective leadership; and Total Quality Control. In the implementation process, the characteristics of the management of the general shape characteristics, namely: Implementation Business Unit Based Learning By Doing; Implementation of Self Berdruing System; Centralized Financial centralization; as well as the creation of balance and Baatinites lahiriyah Welfare.
\end{abstract}

Key Words: Model Business Development, School, Gontor.

\begin{abstract}
Paper ini mencoba menawarkan model pengembangan bisnis Pondok Modern Darussalam Gontor Ponorogo Indonesia. Keberhasilan Pondok Modern Darussalam Gontor dalam mengelola 30 unit usaha membentuk karakteristik tersendiri. Adapun karakteristik pengelolaan unit usaha Pondok Modern Darussalam Gontor adalah: Perencanaan (planning) berbasis nilai Pondok; Pengorganisasian (organizing) berbasis kaderisasi; Kepemimpinan kolektif transformatif; dan Total Quality Control. Dalam proses implementasi, karakteristik pengelolaan tersebut membentuk karakteristik secara umum, yakni: Pelaksanaan Kegiatan Unit Usaha Berbasis Learning By Doing; Implementasi Prinsip Self Berdruing System; Sentralisasi Keuangan Terpusat; serta Terciptanya Keseimbangan Kesejahteraan Lahiriyah dan Batiniyah.
\end{abstract}

Kata Kunci: Model Pengembangan Bisnis, Pesantren, Gontor.

\section{Pendahuluan}

Dalam perkembangan bisnis dewasa ini, kegiatan bisnis dapat dilakukan dengan berbagai cara agar target keuntungan perusahaan tercapai. Akibatnya, cara apapun kemudian dianggap sah asalkan tujuan bisnis dapat tercipta (Chamidi, 2015: 1-23). Dominansi sistem ekonomi barat sebagian besar telah menghapuskan nilai-nilai Islam, keyakinan, serta ide tentang bisnis dan perdagangan (Hasyim, 2012: 98-120).

Praktek bebas nilai yang diberlakukan bagi sebagian besar pembisnis menyebabkan kesenjangan antar lapisan masyarakat, khususnya 
masyarakat menengah kebawah. Seseorang yang berkuasa dengan bebas menindas kaum yang lemah. Eksploitasi Sumber Daya Alam, penipuan, penyalahgunaan kekuasaan semakin marak. Fenomena pelik yang terjadi dengan berkembangnya bisnis kontemporer saat ini menyebabkan tidak adanya keadilan dalam berbisnis.

Dalam melaksanakan aktivitas bisnis, harus ada batasan agar tidak mendzolimi seseorang yang lain. Berikut merupakan landasan dasar terhadap larangan memakan harta yang bathil:

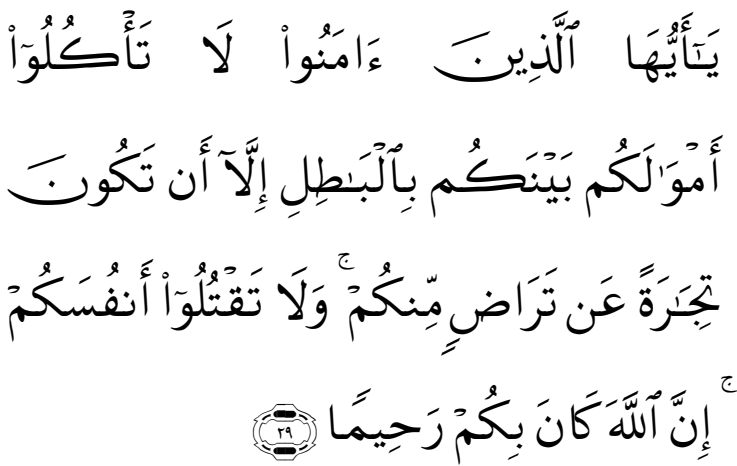

Hai orang-orang yang beriman, janganlah kamu saling memakan harta sesamamu dengan jalan yang batil, kecuali dengan jalan perniagaan yang Berlaku dengan suka samasuka di antara kamu. dan janganlah kamu membunuh dirimu. Sesungguhnya Allah adalah Maha Penyayang kepadamu (Q.S. AnNisa: 29).

Kegiatan bisnis harus terintegrasi dengan ranah Islam. Orientasi bisnis (entrepreneur) yang bervisi sekuler harus sejalan dengan visi dan misi penciptaan manusia. Orientasi pada bisnis Islami mengandung empat komponen, yakni: target hasil, pertumbuhan, keberlangsungan, dan keberkahan (Veitzal, dkk, 2012: 187). Maka makna bisnis dalam Islam bertujuan untuk merealisasikan konsep keseimbangan antara dimensi horizontal dengan dimensi spiritual (Zen, 2012: 40).
Menurut pandangan Islam, ada empat landasan dalam mengembangkan kegiatan bisnis, yaitu kebenaran, kejujuran, keterbukaan, dan keahlian. Sebagaimana prilaku Rasulullah dalam berbisnis yakni mengedepankan nilainilai kejujuran (sidiq), memegang amanah (amanah), menyampaikan (tabligh), dan memiliki kecerdasan (fathonah (Veitzal, dkk, 2013: 47).

Dalam era persaingan bebas dewasa ini, pembangunan kompetensi dan kapasitas santri adalah suatu keharusan. Untuk dapat bersaing secara kompetitif dalam dunia global, pondok pesantren dituntut mampu melahirkan produk dan alumni yang mempunyai kompetensi dan produktif dalam tiga hal. Pertama, kompeten dan produktif secara spiritual. Kedua, kompeten dan produktif secara sosial. Ketiga, alumni pesantren harus kompeten dan produktif secara ekonomi (Harjito, 2008: 1-19).

Banyak pesantren telah berusaha mengembangkan aktivitas ekonomi produktif, baik sebagai bagian dari aktivitas pendidikan para santrinya, maupun aktivitas pesantren dengan masyarakat. Sebagai perwujudan dari pemberdayaan ekonomi, banyak pesantren yang telah mendirikan Koperasi Pondok Pesantren (Kopontren). Jumlah Kopontren di Indonesia sekitar 1.400 unit (Sutatmi, 2011: 1-10).

Salah satu Pesantren yang mandiri dalam kegiatan perekonomiannya adalah Pondok Modern Darussalam Gontor. Gerakan ekonomi di Pondok Modern Gontor telah dimulai sejak tahun 1970, Dalam perkembangannya, unit usaha kian bertambah hingga mencapai 30 unit usaha, yang kemudian digabung dalam satu wadah, yaitu Koperasi Pondok Pesantren (Kopontren) La Tansa (Faqih, dkk, 2012: 23).

Manajemen sangat diperlukan dalam pengelolaan perekonomian di Pesantren. Melihat dari banyaknya 
Pesantren Tradisional yang mati suri akibat tidak dapat mempertahankan kebutuhan santri dan para penghuni pondok yang ada. Manajemen merupakan suatu rangkaian aktivitas (termasuk perencanaan dan pengambilan keputusan, pengorganisasian, kepemimpinan dan pengendalian) yang diarahkan pada sumber-sumber daya organisasi untuk mencapai tujuannya dengan cara yang efektif dan efisien (Grifin, 2004: 8).

\section{Manajemen dan Manajemen Islami}

Manajemen merupakan suatu rangkaian aktivitas (termasuk perencanaan dan pengambilan keputusan, pengorganisasian, kepemimpinan dan pengendalian) yang diarahkan pada sumber-sumber daya organisasi untuk mencapai tujuannya dengan cara yang efektif dan efisien (Griffin, 2004: 8).

Tujuan Manajemen untuk menciptakan Efektivitas (efectiveness) organisasi yang berarti sejauh mana organisasi dapat mencapai tujuan yang ditetapkan, atau berhasil mencapai apapun yang diekrjakan. Efisiensi (efficiency) organisasi adalah jumlah sumber daya yang digunakan untuk mencapai tujuan organisional (Daft, 2013: 9).

Manajer adalah seseorang yang bertanggung jawab dalam pelaksanaan proses manajemen. Manajer berfungsi dalam merencanakan dan membuat keputusan, mengorganisasikan, memimpin, dan mengendalikan sumbersumber daya manusia, finansial, fisik, dan informasi (Griffin, 2004: 9). Menurut tingkatannya, manajemen dapat dibedakan menjadi tiga tingkatan, yaitu (Soekarno, 1982: 47):

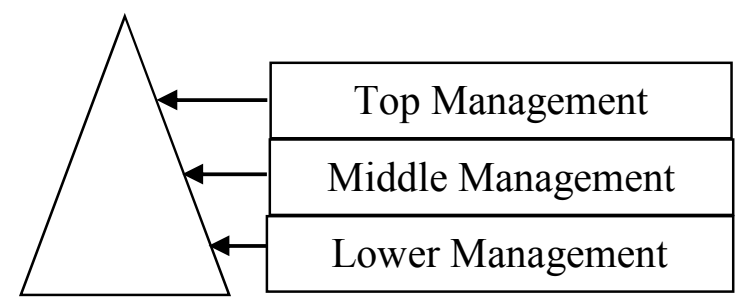

Manajemen juga terdapat unsur unsur didalamnya, unsur-unsur manajemen terdiri dari: men, money, methods, materials, machines, market (6M) (Hasibuan, 2001: 20).

1. Men: Tenaga kerja manusia, baik tenaga kerja pimpinan maupun tenaga kerja operasional/pelaksana

2. Money yaitu uang yang dibutuhkan untuk mencapai tujuan yang diinginkan.

3. Methods yaitu cara-cara yang dipergunakan dalam usaha mencapai tujuan.

4. Materials yaitu bahan-bahan yang diperlukan untuk mencapai tujuan.

5. Machines yaitu mesin-mesin atau alatalat yang dipergunakan untuk mencapai tujuan

6. Market yaitu pasar untuk menjual barang dan jasa-jasa yang dihasilkan.

Manajemen dalam pandangan Islam, segala sesuatu harus dilakukan secara rapi, benar, tertib, teratur, dan tuntas, serta tidak boleh dilakukan secara asalasalan. Apa yang diatur dalam Islam ini telah menjadi indikator pekerjaan manajemen yang meliputi rapi, benar, tertib, teratur, dan sistematis (Ma'ruf, 2012: 13). Diantara ayat Al-Qur'an yang menjadi dasar kegiatan manajemen:

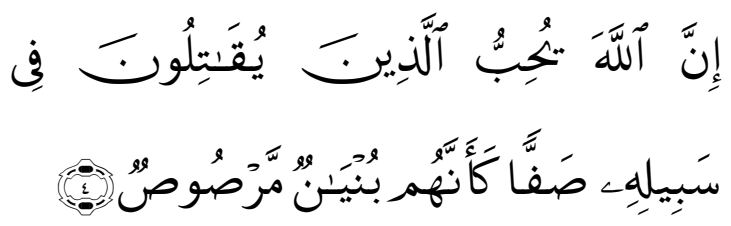

"Sesungguhnya Allah menyukai orang yang berjuang di jalan-Nya dalam barisan yang teratur seakan-akan mereka seperti suatu bangunan yang tersusun kokoh" (Q.S. AshShaff: 4) 
Ada empat landasan untuk mengembangkan manajemen menurut pandangan Islam, yaitu: Kebenaran; Kejujuran; Keterbukaan; dan Keahlian. Seorang manajer harus memiliki empat sifat utama itu agar manajemen yang dijalankannya mendapatkan hasil yang maksimal (Veitzal, dkk 2013: 15).

Agama Islam mengajarkan agar manusia hidup efisien atau tidak berlebihlebihan, atau tidak melewati batas tetapi haruslah seimbang. Prinsip atau metode yang dapat dijadikan sebagai tolak ukur

\begin{tabular}{|c|c|c|c|}
\hline No & Objek & Konvensional & Islam \\
\hline 1 & $\begin{array}{l}\text { Manusia } \\
\text { sebagai }\end{array}$ & $\begin{array}{l}\text { Homo Economicus } \\
\text { (Mahluk ekonomi) }\end{array}$ & $\begin{array}{l}\text { Spiritual Creature } \\
\text { (Mahluk spiritual) }\end{array}$ \\
\hline 2 & $\begin{array}{l}\text { Motivasi } \\
\text { Utama }\end{array}$ & $\begin{array}{l}\text { Motivasi Dunia } \\
\text { (Laba Jangka Pendek) }\end{array}$ & $\begin{array}{l}\text { Rahmat dan Ridho Allah } \\
\text { (Profit dan kebahagiaan } \\
\text { dunia dan akhirat) }\end{array}$ \\
\hline 3 & Pengelolaan & Good Corporate Governance & Good Corporate Governance \\
\hline 4 & $\begin{array}{l}\text { Fungsi } \\
\text { CEO }\end{array}$ & $\begin{array}{l}\text { Pusat koordinasi yang segala } \\
\text { instruksinya harus } \\
\text { dilaksankaan bawahan }\end{array}$ & $\begin{array}{l}\text { CEO memfasilitasi } \\
\text { lingkungan dengan spirit } \\
\text { moral yang dapat } \\
\text { dipertanggung jawabkan } \\
\text { kepada manusia dan Tuhan. } \\
\text { Kru tidak pada posisi pasif, } \\
\text { sebaliknya } \\
\text { memberikan masukan dan } \\
\text { pemikiran. }\end{array}$ \\
\hline 5 & $\begin{array}{l}\text { Fokus } \\
\text { Bisnis }\end{array}$ & Maksimalisasi Laba & $\begin{array}{l}\text { Bisnis yang beretika dan } \\
\text { berkelanjutan }\end{array}$ \\
\hline
\end{tabular}

Fungsi manajemen pada hakikatnya merupakan tugas pokok yang harus dijalankan pimpinan dalam organisasi apapun (Syamsi, 1988: 60). Namun, Fungsi-fungsi manajemen yang dikemukakan para penulis tidak sama. Hal ini disebabkan latar belakang penulis dan pendekatan yang dilakukan yang berbeda (Hasibuan, 2001: 37).

Fungsi pokok manajemen yang berkembang saat ini umumnya terbagi menjadi empat:

a. Perencanaan (Planning) bagi umat Islam untuk mengatur hidupnya agar selalu efisien adalah: Keseimbangan (tawazun); Mencapai kemanfaatan; Tidak Mubadzir; dan Adil (Effendi, 1986: 154).

Dalam Islam, manajemen dipandang sebagai perwujudan amal sholeh yang harus bertitik tolak dari niat baik (Veitzal, dkk 2013: 47).

Berikut merupakan perbandingan konsep manajemen konvensional dan Islam (Amin, 2010: 67). 
Sebagaimana dalam Al-Qur'an Allah SWT berfirman:

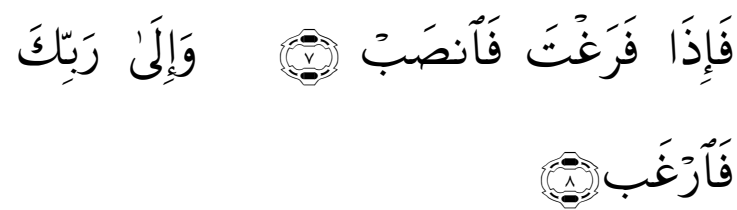

"Maka apabila kamu telah selesai (dari suatu urusan), kerjakanlah dengan sungguh-sungguh (urusan) yang lain. Dan hanya kepada Tuhanmulah hendaknya kamu berharap" (2.S. Al-Insyirah: 7-8)

b. Pengorganisasian (Organizing)

Proses pengorganisasian (organizing) terkait: Pembagian Tugas, Menentukan Orang-orang untuk melaksanakan tugas tersebut, Pengalokasian sumber daya, Menyelaraskan usaha, dan Bekerja sama dalam melaksanakan tugas (Sule dan Saefullah, 2005: 11).

Dalam Konteks Islam, Pengorganisasian (Organization) merupakan wadah tentang fungsi setiap orang, hubungan kerja baik secara vertikal maupun horizontal. Sebagaimana Allah SWT berfirman:

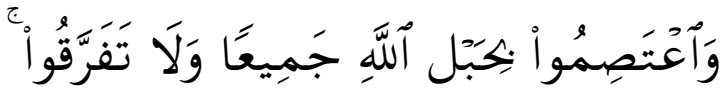

"Dan berpeganglah kamu semuanya kepada tali (agama) Allah, dan janganlah kamu bercerai berai" (Q.S. Ali Imran: 103)

c. Kepemimpinan (Leading)

Proses kepemimpinan (leading) terkait: Bertanggung Jawab, Memegang Amanat, Bertakwa, Memberikan arahan dan motivasi, Mengevaluasi kinerja staff,
Memimpin diri sendiri, Adil (Veitzal, dkk, 2013: 191).

Dalam konteks Islam, pemimpin tidak hanya fokus kepada seseorang yang memimpin institusi formal dan nonformal. Tuntutan Islam lebih universal bahwa kepemimpinan itu lebih spesifik lagi kepada setiap manusia yang hidup ia merupakan pemimpin, baik memimpin dirinya sendiri maupun kelompoknya. Dengan demikian, kepemimpinan dalam ajaran Islam dimulai dari setiap individu (Veitzal, dkk, 2013: 191). Sebagaimana Allah SWT berfirman:

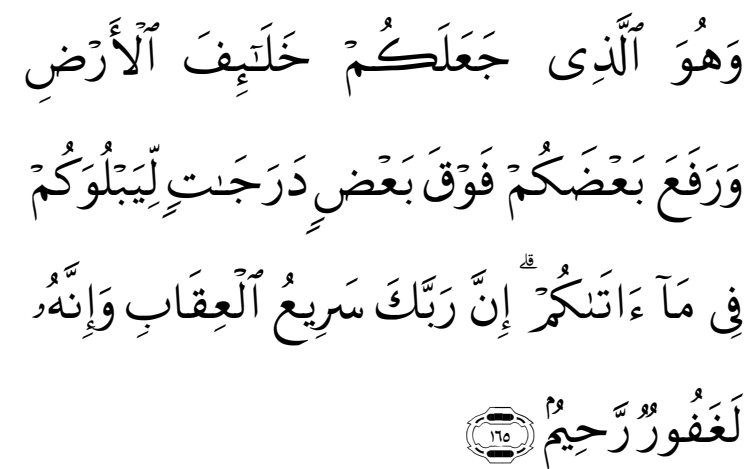

"Dan dia lah yang menjadikan kamu penguasa-penguasa di bumi dan dia meninggikan sebagian kamu atas sebagian lain beberapa derajat, untuk mengujimu tentang apa yang diberikanNya kepadamu. Sesungguhnya Tuhanmu amat cepat siksaan-Nya dan Sesungguhnya dia Maha Pengampun lagi Maha Penyayang." (२.S. Al-An'am: 165)

d. Pengontrolan (Controlling)

Tujuan dalam proses pengawasan (controlling) adalah untuk mengevaluasi keberhasilan dalam pencapaian tujuan dan target bisnis sesuai dengan indikator yang telah ditetapkan (Sule dan Saefullah, 2005: 11).

Seorang manajer orang terbaik dan harus mengontrol seluruh anggotanya dengan baik (Veitzal, 
dkk, 2013: 189). Sebagaimana Allah SWT berfirman bahwa kontrol utama ialah dari Allah:
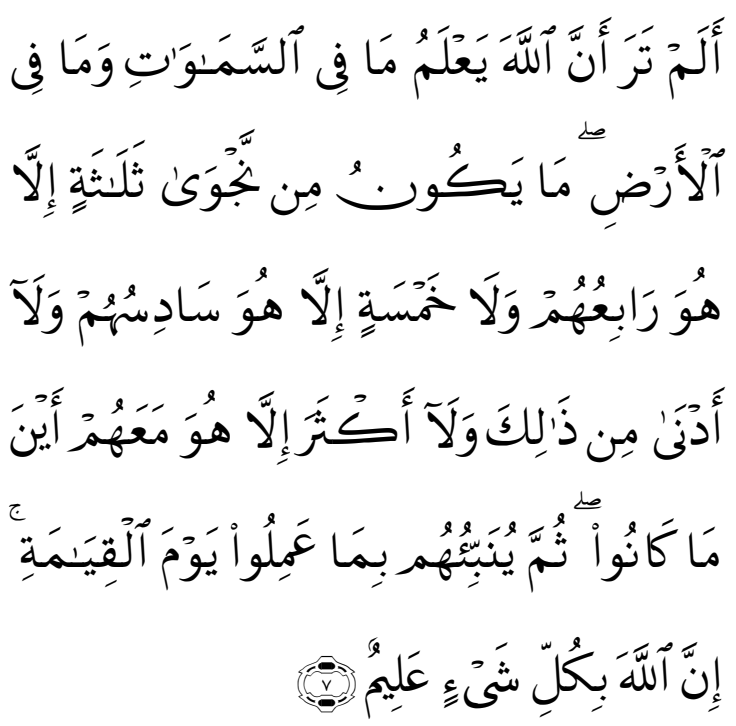

"Tidakkah kamu perhatikan, bahwa sesungguhnya Allah mengetahui apa yang ada di langit dan di bumi ? tiada pembicaraan rahasia antara tiga orang, melainkan Dia-lah keempatnya, dan tiada (pembiacaraan antara) lima orang, melainkan Dia-lah keenamnya, dan tiada (pula) pembicaraan antara jumlah yang kurang dari itu atau lebih banyak, melainkan dia berada bersama mereka di manapun berada. Kemudian dia akan memberitahukan kepada mereka pada hari kuamat apa yang Telah mereka kerjakan. Sesungguhnya Allah Maha mengetahui segala sesuatu" (2.S. Al-Mujadalah:7).

\section{Konsep Bisnis Dalam Islam}

Dalam Al-Qur'an istilah entrepreneur atau bisnis disebut dengan menggunakan term tijarah (perniagaan), bai'a wa isytara (jual-beli) dan tadayantum (akad utang piutang). Menurut Raghib Al-Asfahani, kedua kata tersebut memiliki makna yang serupa yaitu pengelolaan harta benda dengan tujuan mencari keuntungan (Haryadi, 2011: 5). Berikut merupakan Landasan Dasar seorang Entrepreneur dalam mengikuti jejak Rasul dalam perilaku bisnis:

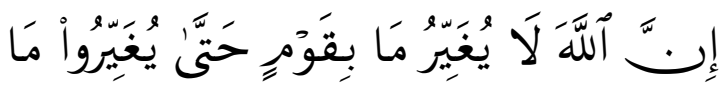

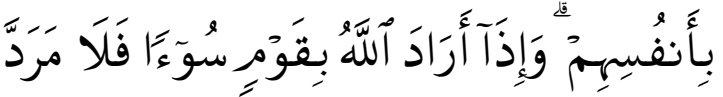

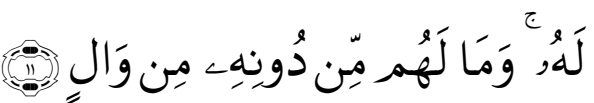

"Sesungguhnya Allah tidak merobah Keadaan sesuatu kaum sehingga mereka merobah keadaan yang ada pada diri mereka sendiri. dan apabila Allah menghendaki keburukan terhadap sesuatu kaum, Maka tak ada yang dapat menolaknya; dan sekali-kali tak ada pelindung bagi mereka selain Dia (Q.S. ArRa'd: 11).

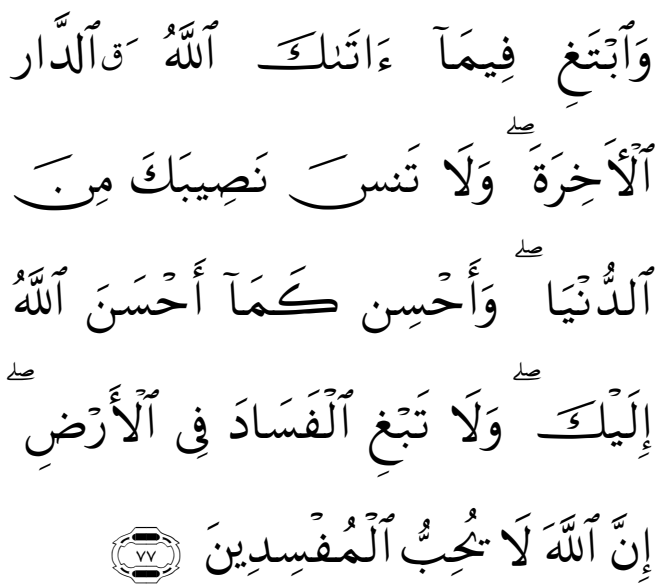

Dan carilah pada apa yang telah dianugerahkan Allah kepadamu (kebahagiaan) negeri akhirat, dan janganlah kamu melupakan bahagianmu dari (kenikmatan) duniawi dan berbuat baiklah (kepada orang lain) sebagaimana Allah telah berbuat baik, kepadamu, dan janganlah kamu berbuat kerusakan di (muka) bumi. Sesungguhnya Allah tidak menyukai orang-orang yang berbuat kerusakan (2.S. Al- Qoshosh: 77).

Al-Qur'an memberikan petunjuk akan pentingnya keseimbangan antara kehidupan di dunia maupun akhirat. 
Manusia sebagai Khalifah Fil Ardh harus mampu mengelola apa yang ada di muka bumi ini menjadi lebih bermanfaat. Hal tersebut mengindikasikan bahwa, pentingnya bisnis (entrepreneur) dilaksanakan di muka bumi ini.

Posisi kerja keras dalam berbisnis merupakan bagian dari keberhasilan seseorang, maka Islam memberikan penghargaan yang sangat tinggi kepada mereka yang melakukannya. Ibrahim AthThahawi dan Abdul Munim Khallaf menyatakan bahwa kerja adalah sebuah faridhah (kewajiban), dimana setiap orang akan dimintai pertanggung jawaban (Multitama, 2006: 125).

Kegiatan Bisnis dalam konsep Islami tidak hanya dalam hal memperoleh keuntungan materi, melainkan sebagai media ibadah guna mendapatkan tiket menuju kebahagiaan abadi di akhirat kelak (Multitama, 2006: 150). Bisnis dalam Islam mengutamakan keuntungan dan maksimalisasi maslahah. Al-Syaibani sebagai pakar pemikir ekonomi Islam mendifinisikan kerja sebagai mencari perolehan harta melalui berbagai cara yang halal. Al-Syaibani juga menyatakan bahwa bekerja merupakan ajaran para rasul terdahulu dan kaum Muslimin diperintahkan untuk meneladani cara hidup mereka (Karim, 2004: 259).

Islam memandang bahwa tujuan suatu amal perbuatan tidak hanya berorientasi pada materi (Vimah Madiyah), masih ada tiga orientasi lainnya, yakni nilai kemanusiaan (Qimah Insaniyah), nilai akhlak (Qimah Khuluqiyah), dan nilai ruhiyah (Qimah Ruhiyah) (Veitzal, 2012: 187-188).

a. Nilai Kemanusiaan (Qimah Insaniyah)

Dengan berorientasi qimah insaniyah berarti pengelola sebuah perusahaan atau organisasi juga dapat memberikan manfaat yang bersifat kemanusiaan baik melalui kesempatan kerja maupun bantuan sosial dan lain-lain.

b. Nilai Akhlak (Qimah Khuluqiyah)

Qimah khuluqiyah mengandung pengertian bahwa, akhlaqul karimah menjadi suatu kemestian yang harus muncul dalam setiap aktivitas para pengelola organisasi.

c. Nilai Ruhiyah (qimah ruhiyah)

Qimah ruhiyah berarti perbuatan tersebut dimaksudkan untuk mendekatkan diri kepada Allah swt.

Menurut pandangan Islam, ada empat landasan dalam mengembangkan kegiatan bisnis, yaitu kebenaran, kejujuran, keterbukaan, dan keahlian. Sebagaimana prilaku Rasulullah dalam berbisnis yakni mengedepankan nilainilai kejujuran (sidiq), memegang amanah (amanah), menyampaikan (tabligh), dan memiliki kecerdasan (fathonah) (Veitzal, 2013: 47).

Berikut merupakan perbandingan karakteristik bisnis yang berbasis Islam dengan bisnis yang terjadi pada umumnya (Oci, 2012: 87).

Perbandingan Karakteristik Bisnis Islami dan Bisnis NonIslami.

\begin{tabular}{|l|l|l|}
\hline \multicolumn{1}{|c|}{$\begin{array}{c}\text { KARAKTERISTIK } \\
\text { BISNIS }\end{array}$} & \multicolumn{1}{c|}{ ISLAMI } & \multicolumn{1}{c|}{ NON ISLAMI } \\
\hline ASAS & $\begin{array}{l}\text { Tauhid } \\
\text { (nilai-nilai transedental) }\end{array}$ & $\begin{array}{l}\text { Sekularisme } \\
\text { (nilai-nilai material) }\end{array}$ \\
\hline MOTIVASI & Dunia-akhirat & Dunia \\
\hline ORIENTASI & Profit dan berkah & Profit \\
\hline ETOS KERJA & $\begin{array}{l}\text { Tinggi, } \\
\text { bekerja adalah ibadah }\end{array}$ & $\begin{array}{l}\text { Tinggi, bekerja adalah } \\
\text { kebutuhan duniawi }\end{array}$ \\
\hline SIKAP MENTAL & Sukses dunia dan akhirat & Sukses dunia \\
\hline
\end{tabular}




\begin{tabular}{|l|l|l|}
\hline KEAHLIAN & Kewajiban seorang muslim & Kewajiban perusahaan \\
\hline MODAL & Halal & Halal dan Haram \\
\hline AMANAH & $\begin{array}{l}\text { Terpercaya dan bertanggung } \\
\text { jawab, } \\
\text { tujuan tidak menghalalkan } \\
\text { cara }\end{array}$ & $\begin{array}{l}\text { Tergantung } \\
\text { individu } \\
\text { kapital), } \\
\text { tujuan menghalalkan cara }\end{array}$ \\
\hline SDM & Beriman dan bertakwa & $\begin{array}{l}\text { Tidak beriman dan } \\
\text { Bertakwa (Duniawi) }\end{array}$ \\
\hline
\end{tabular}

Dalam menjalankan suatu usaha harus memegang teguh prinsip-prinsip kewirausahaan Islami. Berikut merupakan tiang-tiang pokok kewirausahaan dalam Islam (Fasa, 2012: 65):

a. Wajib Bekerja

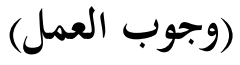

b. Memberantas pengangguran<smiles>[14CH3][14CH3]</smiles>

c. Pengakuan hak milik pribadi<smiles>[13CH2][13CH3]</smiles>

d. Harta itu nikmat Allah

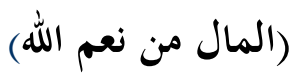

e. Memberdayakan harta untuk kemashlahatan agama dan masyaraka

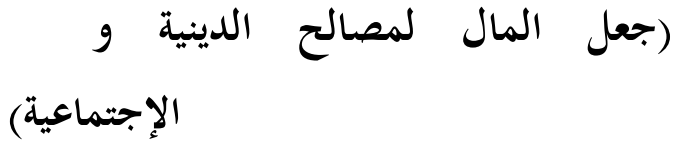

\section{Potensi Perkembangan Perekonomian Pesantren}

Seiring dengan pertumbuhan pesantren yang begitu pesat, maka, potensi ekonomi yang ada dalam pesantren juga begitu besar. Dengan kemampuan manajemen yang baik, usaha produktif yang dikembangkan dapat meningkatkan kemandirian keuangan pesantren. Harapannya, pesantren dapat menjadi salah satu sarana pendidikan yang terjangkau oleh masyarakat namun tetap tidak mengorbankan kualitasnya (Widodo, 2011).

Munculnya usaha ekonomi pesantren dimulai kebutuhan pesantren untuk menghidupi dirinya (survive) dan dalam rangka mengembangkan peran pesantren sebagai bentuk pengabdian masyarakat (Yusuf dan Suwito, 2010: 17). Pesantren membutuhkan peran instrument ekoproteksi secara kukuh dalam mengembangkan dan melindungi manajemen ekonomi yang sedang dilaksanakan, yaitu peran kyai, pendidik, lembaga, serta pemerintah (Azizah, 2014: 182-184).

Pilihan aktivitas ekonomi (bisnis) ditentukan oleh kemampuan pengelola pesantren membaca, mendefinisikan, memanfaatkan, dan mengorganisasikan resources, baik internal maupun eksternal. Jenis-jenis usaha ekonomi yang dapat dikembangkan pada pesantren umumnya dapat diklasifikasikan ke dalam 4 kelompok besar, yaitu: Agribisnis (pertanian, perikanan, perkebunan); Jasa (KBIH, percetakan, Lazis, BMT, koperasi); Perdagangan (ritel, pertokoan, agen penjualan), serta Industri (penjernihan air, meubeler) (Yusuf dan Suwito, 2010: 268). Keberadaan berbagai unit usaha ini merupakan salah satu sarana pendidikan di bidang kemandirian, kewiraswastaan, keikhlasan, dan pengorbanan. Seluruh usaha milik pondok ini dikelola santri dan guru, hasilnya dipergunakan untuk memenuhi kebutuhan pondok, santri, dan guru (Zarkasyi, 2005: 185).

Para santri didik dan dibina dalam meningkatkan jiwa kewirausahaan (Faozan, 2006: 1-12). Pondok pesantren memiliki peran yang sangat strategis. 
Selain sebagai pusat pengembangan agama, pendidikan, sosial dan budaya, pesantren juga merupakan salah satu kekuatan ekonomi (Daniar, 2013: $203-$ 216). Dalam segala potensinya, Pesantren dapat membangun model bisnis melalui proses terpadu, Keunggulan daya saing entitas bisnis pesantren merupakan konsekuensi model bisnis berbasis ukhuwah, serta dapat mengantarkan pesantren dan masyarakat pada keberdayaan ekonomi dan tingkat kesejahteraan yang baik (Fauroni, 2013: 255-257).

Perkembangan pesantren pada masa lalu banyak memiliki kelemahan, utamanya disebabkan karena tidak diimbangi kemampuan dan profesionalisme yang memadai (Zailani, 2008: 124). Seperti tidak ada pemisahan yang jelas antara yayasan, pimpinan madrasah, guru dan staff administrasi. Tidak adanya transparansi pengelolaan sumber-sumber keuangan, belum terdistribusinya peran pengelolaan pendidikan, banyaknya penyelenggaraan administrasi yang tidak sesuai standar, serta unit-unit kerja tidak berjalan sesuai aturan baku organisasi (Masyhud dan Khusnurdilo, 2004: 16).

Masa depan pesantren sangat ditentukan oleh faktor manajerial. Pesantren kecil akan berkembang secara signifikan manakala dikelola secara profesional. Dengan pengelolaan yang sama, pesantren yang sudah besar akan bertambah besar. Sebaliknya, pesantren yang telah maju akan mengalami kemunduran manakala manajemennya tidak baik. Jika mengabaikan manajemen, pesantren yang kecil akan gulung tikar dalam menghadapi tantangan multidimensi (Mujail, 2002: 63).
Faktor
yang menentukan
kemampuan pesantren untuk melaksanakan fungsionalisasi perannya dalam pemberdayaan bisnis adalah pengelolaan dan kepemimpinan

pesantren, sumber daya manusia, dukungan masyarakat dan dukungan pemerintah (Supi, 2009: 161-163). Model pembinaan ekonomi santri dapat dilaksanakan dengan melibatkan santri dalam usaha ekonomi (agrobisnis). Serta model pemberdayaan ekonomi masyarakat sekitar pesantren dilakukan dengan pola kemitraan dengan Lembaga Mandiri yang Mengakar di Masyarakat (LM3) (Muttaqin, 2010: 180).

Dalam pelaksanaan kegiatan bisnis di pesantren, guru-guru sebagai staf secara langsung merencanakan, mengkoordinasikan, mengorganisasikan, serta mengevaluasi program-program yang telah dijalankan bersama kyai serta Badan Wakaf dan saling bersinergi untuk menentukan keputusan bersama (Daniar, 2013: 203-216).

Perubahan pesantren dari pesantren tradisional menuju pesantren modern, serta menjadikan pesantren yang berkolaborasi terhadap entitas bisnis pada pesantren yang ada (Fauroni, 2013: 24). Pondok pesantren merupakan lembaga pendidikan untuk mencetak manusia yang religius dan mandiri. (Indra, 2005: 77).

Dalam menerapkan manajemen bisnis pesantren, beberapa langkah harus dilakukan sebagai berikut: Pertama, motivasi dari pimpinan dan manajer di pesantren, Kedua, pengamalan nilai-nilai pondok pesantren, Ketiga, keterlibatan dalam komunitas, Keempat, relasi antara pesantren dan lembaga lain, Kelima, administrasi dan pembiayaan yang efisien (Rohmah, 2009: 187-201).

Pondok pesantren dengan berbagai harapan dan predikat yang dilekatkan padanya, sesungguhnya berujung pada tiga fungsi utama, yaitu: Pertama, sebagai pusat pengkaderan pemikir-pemikir agama (Center of Excellence). Kedua, sebagai lembaga yang mencetak sumber daya manusia (Human Resource). Ketiga, sebagai lembaga yang mempunyai kekuatan 
melakukan pemberdayaan pada masyarakat (Agent of Development) (Suhartini, 2009: 233).

\section{Perkembangan Pondok Modern Darussalam Gontor di Indonesia}

Secara historis Pondok Modern

Darussalam Gontor berasal dari pondok pesantren tradisional yang terletak di Tegalsari $10 \mathrm{KM}$ sebelah selatan kota Ponorogo atau $3 \mathrm{KM}$ sebelah barat Gontor sekarang. Pondok ini didirikan oleh Kiyai Ageng Muhammad besari pada abad ke-18 dan mencapai puncaknya ketika dipimpin oleh Kyai Hasan Anom Besari (1800-1862) (Praja dan Muzarie, 2009: 176).

Kebangkitan Darussalam menjadi pondok pesantren modern diawali oleh KH.Ahmad Sahal, 12 Rabi'ul Awal 1345 H atau 9 Oktober 1926 M. KH Ahmad Sahal adalah kakak dari KH. Zainuddin Fanani dan KH. Imam Zarkasyi. Ketika Pesantren tersebut tengah mengawali untuk memodernisasi dirinya. Imam Zarkasyi sedang belajar di Solo (1925) dan melanjutkan ke Sekolah Normal Islam, pimpinan Mahmud Yunus di Padang, Sumatera Barat. Sedangkan Zainuddin Fanani menjadi School Opzsier di Bengkulen. Mereka belajar kepada kiyai pondok itu dengan penuh ketekunan dan keikhlasan; mempergunakan ilmu yang telah didapat dan menyebarkanya kepada kalangan masyarakatnya masing-masing (Tim Penyusun, 1997: 12).

Langkah pertama yang dilakukan Kyai Ahmad Sahal untuk memperbaiki kondisi masyarakat tersebut adalah membina dan mendidik anak-anak desa dengan kegiatan pendidikan Tarbiyatul Athfal (Pendidikan Anak-anak) (1926). Dengan adanya kegiatan-kegiatan kependidikan tersebut, orang-orang dari luar desa mulai berdatangan ke Gontor. Karena banyaknya peminat, Tarbiyatul Athfal Gontor membuka beberapa cabang di desa-desa sekitar Gontor yang kemudian diberi nama Tarbiyatul Islam (Pendidikan Islam) (Tim Penyusun, 1996: 43).

Tujuan pondok modern gontor yang paling utama adalah untuk mempersiapkan kader-kader bagi masyarakat Islam di Indonesia, dengan mengkombinasikan kelebihan-kelebihan sistem pendidikan Pondok kuno dengan teori dan praktek pendidikan modern. Berbagai model-model lembaga pendidkan yang telah memperngaruhi Gontor, mereka menyebut Al-Azhar, Aligarh, Shantiniketan, dan Syanghit (Castles, 1991: 3)

Pondok Modern Darussalam Gontor merupakan salah satu Pondok Pesantren yang sangat berperan dalam mewarnai pendidikan Indonesia bahkan Asia Tenggara. Seluruh potensi dan kemampuan dicurahkan untuk merealisasikan misi tersebut. Hal ini semakin dipertegas dengan tidak terlibatnya Pondok Modern Darussalam Gontor dalam politik praktis, serta tidak berafiliasi kepada organisasi kemasyarakatan apapun, sehingga dapat secara independen menentukan langkah dan memiliki ruang gerak yang lebih luas dalam bidang pendidikan dan pengajaran (Suharto, 2011: 1).

Pondok Modern Darussalam Gontor Berkembanga Begitu Pesat. Berikut merupakan rekapitulasi perkembangan Pondok Modern Darussalam Gontor.

\section{Rekapitulasi Guru dan Santri}

Pondok Modern Darussalam Gontor . ${ }^{1}$

${ }^{1}$ Data Adopted From Secretary Department of Darussalam Modern Gontor Islamic Institution 18 April 2017. 


\begin{tabular}{|c|l|l|c|}
\hline No & \multicolumn{1}{|c|}{ Pondok Modern Darussalam } & \multicolumn{1}{|c|}{ Location } & Amount \\
\hline 1 & Gontor 1 & Gontor Ponorogo & 4.498 \\
\hline 2 & Gontor 2 & Madusari Ponorogo & 1.385 \\
\hline 3 & Gontor 3 & Nggu urah Kediri & 1.595 \\
\hline 4 & Gontor For Girl 1 & Mantingan Ngawi & 3.930 \\
\hline 5 & Gontor For Girl 2 & Mantingan Ngawi & 1.184 \\
\hline 6 & Gontor For Girl 3 & Karangbanyu Ngawi & 2.805 \\
\hline 7 & Gontor For Girl 4 & Kendari Sul Tenggara & 325 \\
\hline 8 & Gontor For Girl 5 & Kandangan Kediri & 1.352 \\
\hline 9 & Gontor For Girl 6 & Poso Sulawesi Tengah & 144 \\
\hline 10 & Gontor For Girl 7 & Pekan Baru Riau & 893 \\
\hline 11 & Gontor 5 & Kaliagung Banyuwangi & 1.279 \\
\hline 12 & Gontor 6 & Magelang Jawa Tengah & 1.315 \\
\hline 13 & Gontor 7 & Kendari Sul Tenggara & 353 \\
\hline 14 & Gontor 8 & Way Jepara Lampung & 21 \\
\hline 15 & Gontor 9 & Kalianda Lampung & 635 \\
\hline 16 & Gontor 10 & Darul Amin Aceh & 141 \\
\hline 17 & Gontor 11 & Sulit Air Padang & 69 \\
\hline 18 & Gontor 12 & Tanjung Jabung Timur & 380 \\
& & Jambi & 190 \\
\hline 19 & Gontor 13 & Poso Sulawesi Tengah & 178 \\
\hline 20 & Gontor 14 & Siak, Riau & 1.073 \\
\hline 21 & University of Darussalam Gontor & Siman & 108 \\
\hline 22 & MBUD & Mantingan & \\
\hline & TOTAL & & $\mathbf{2 3 5 3}$ \\
\hline & & & \\
\hline
\end{tabular}

Gerakan ekonomi di Pondok Modern Gontor telah dimulai sejak tahun 1970, ketika dibuka usaha penggilingan padi. Dalam perkembangannya, unit usaha kian bertambah, yang kemudian digabung dalam satu wilayah, yaitu Koperasi Pondok Pesantren La Tansa. Secara resmi, kopontren dibuka dan didaftarkan ke Departemen Koperasi, dengan No. 8371/BH/II/1996, bulan Juli 1996 (Faqih, dkk, 2012: 23).

Adanya Kopontren merupakan salah satu bukti pengamalan jiwa kemandirian yang terkandung dalam Panca Jiwa Pondok Modern. Artinya, dalam pembiayaan, Pondok tidak tergantung pada belas kasihan pihak lain. Karena itu, Pondok mendirikan usahausaha yang dikelola oleh para guru dan santri. Hasilnya untuk menunjang proses pendidikan dan pengajaran (Tim Redaksi WARDUN, 2009: 33).

Ajaran pendidikan yang utama dalam pondok pesantren Gontor ialah Ali'tibar 'Ala Annafsi (الإعتبار على النفسى) , dalam bahasa Belanda Zelp Help, dengan kata lain, belajar mencukupi atau menolong diri sendiri dan tidak menggantungkan. orang lain. Pondok 
Modern Darussalam Gontor melakukan aktivitas unit usahanya menggunakan Self Berdruifing System, yakni dengan pendekatan filosofi: pondok merupakan kepunyaan bersama, dan bukan hak milik pribadi. Setiap datang pelajar santri baru, berarti bertambah satu anggota yang turut bertanggung jawab atas keberlangsungan pondok. Pembayaran yang diberikan merupakan iuran(urusan pondok/sekolah). Dengan iuran yang diberlakukan kepada setiap santri, maka iuran tersebut akan dipergunakan untuk kepentingan pondok (Panitia Pekan Perkenalan Khutbatul Arsy, 2013: 11).

Semua hasil usaha masuk ke kas pondok pada bagian Administrasi, dan tidak ada yang masuk ke kantong pribadi, baik kyai maupun guru pengelola. Di antara pemanfataannya adalah untuk pembiayaan jangka kesejahteraan keluarga, pembangunan fasilitas pendidikan, serta kaderisasi (Tim Redaksi WARDUN, 2014: 54). Kesejahteraan tersebut dikelola oleh Kopontren La
Tansa dibawah manajemen YPPWPM, Sehingga bukan hanya kesejahteraan guru yang meningkat, tanah wakaf juga mengalami perluasan yang signifikan (Tim Redaksi WARDUN, 2012: 23).

Para guru pengelola unit usaha tersebut tidak dibayar. Namun, dengan ikut mengelola unit usaha, para guru dapat belajar banyak hal. Sebab, bagi pondok, unit usaha juga merupakan sarana pendidikan: pendidikan tanggung jawab dan pendidikan kewirausahaan (Tim Redaksi WARDUN, 2014: 54).

Dengan prinsip kemandirian tersebut, Gontor kian maju berkembang, sehingga kini seakan tiada henti Pondok Modern menuai hasil dari prinsip kemandiriannya, terutama dalam aspek ekonomi. Gontor menggali dan mengembangkan sektor ekonomi dibawah naungan Koperasi Pesantren La Tansa (Tim Redaksi WARDUN, 2008: 50). Berikut merupakan unit-unit usaha yang dimiliki Kopontren (Tim Redaksi WARDUN, 2012: 23).

Data Unit Usaha Pondok Modern Darussalam Gontor.

\begin{tabular}{|l|l|l|}
\hline \multicolumn{1}{|c|}{ UNIT USAHA } & \multicolumn{1}{c|}{ LETAK } & BERDIRI \\
\hline Penggilingan Padi & Ds.Gontor & 1970 \\
\hline Percetakan Darussalam & Ds. Gontor & 1983 \\
\hline KUK Palen & Ds. Bajang & 1985 \\
\hline KUK Toko Besi & Ds. Bajang & 1988 \\
\hline Toko Buku La Tansa & Ponorogo & 1989 \\
\hline UKK Mini Market & Ds. Gontor & 1990 \\
\hline Bakso La Tansa & Ponorogo & 1990 \\
\hline KUK Fotocopy & Ds. Bajang & 1990 \\
\hline Wartel Gambia & Ds. Gontor & 1991 \\
\hline Apotik La Tansa & Ponorogo & 1991 \\
\hline Pabrik Es & Ds. Gontor & 1996 \\
\hline Perkulakan & Ds. Gontor & 1997 \\
\hline Kendaraan & Ds. Gontor & 1998 \\
\hline Kantin Al-Azhar & Ds. Gontor & 1999 \\
\hline Wisma Darussalam & Ds. Gontor & 1999 \\
\hline Wartel Sudan & Ds. Gontor & 1999 \\
\hline Darussalam Computer Center & Ds. Gontor & 1999 \\
\hline
\end{tabular}




\begin{tabular}{|l|l|l|}
\hline Fotocopi Asia & Ds. Gontor & 2000 \\
\hline La Tansa Timur & Ds. Gontor & 2002 \\
\hline Potong Ayam & Ds. Gontor & 2002 \\
\hline La Tansa DC Mantingan & Mantingan & 2003 \\
\hline Pabrik Roti & Ds. Gontor & 2003 \\
\hline Air Minum La Tansa & Ds. Gontor & 2004 \\
\hline Toko Alat Olahraga & Ponorogo & 2005 \\
\hline Konveksi & Ds. Gontor & 2006 \\
\hline Wartel Al-Azhar & Ds. Gontor & 2006 \\
\hline Mie Ayam & Ds. Gontor & 2006 \\
\hline Teh La Tansa & Ds. Gontor & 2009 \\
\hline BMT La Tansa & Ds. Gontor & 2010 \\
\hline BMT Siman & Siman & 2011 \\
\hline Es Krim & Ds. Gontor & 2012 \\
\hline
\end{tabular}

Manajemen Bisnis Pondok Modern Darussalam Gontor Ponorogo

Secara resmi, kopontren dibuka dan didaftarkan ke Departemen Koperasi, dengan No.8371/BH/II/1996, bulan Juli 1996. Adanya Kopontren merupakan salah satu bukti pengalaman jiwa kemandirian yang terkandung dalam Panca Jiwa Pondok Modern. Dengan kemandirian, pondok tidak bergantung kepada bantuan pihak lain. Terbukti, dengan kemandiriannya, saat ini terdapat 30 unit usaha yang dimiliki pondok.

Berdasarkan Penelitian yang telah dilakukan, berikut merupakan Skema Model Implementasi Manajemen Bisnis Pondok Modern Darussalam Gontor:

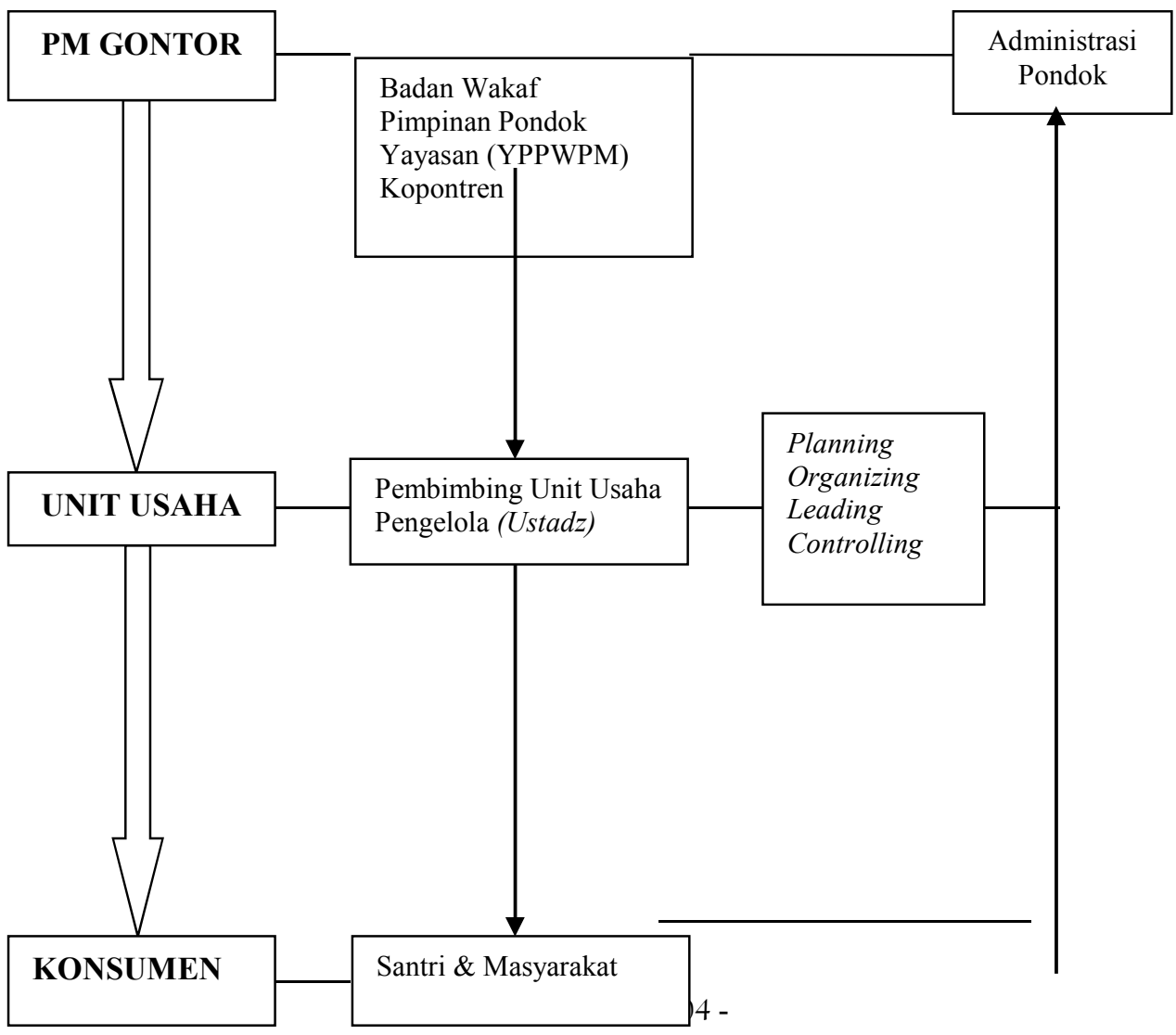


Proses pelaksanaan perencanaan (planning) yang diberlakukan pada unit usaha Pondok Modern Darussalam Gontor kurang baik. Proses perencanaan yang sederhana serta ditutupnya unit usaha KUK Fotocopy merupakan salah satu indikator kurang baiknya proses pelaksanaan perencanaan (planning) yang diberlakukan tanpa memperhitungkan target jangka panjang, business plan, strategic plan, dan analisis kelayakan bisnis secara mendalam.

Implementasi pengorganisasian (organizing) yang diberlakukan oleh Pondok Modern Darussalam Gontor dapat digolongkan dalam kriteria sedang. Hal tersebut disebababkan adanya beberapa kelemahan dalam praktek pengorganisasian (organizing). Seperti adanya pembagian secara double section pada unit usaha, serta 3 pimpinan yang memiliki otoritas sama dalam pengambilan keputusan.

Kepemimpinan (leading) dilakukan secara bersama, sehingga dapat menutupi kekurangan antara satu dengan lainnya, khususnya kepemimpinan dalam bidang pengelolaan unit usaha. Dengan satu kesatuan yang utuh, maka proses pelaksanaan arahan, motivasi, serta bimbingan dapat dilakukan secara baik. Dengan demikian, praktek kepemimpinan (leading) Pondok Modern Darussalam Gontor tergolong dalam kriteria baik. Terlebih, figur karismatik kiyai (pimpinan) memiliki kekuatan (power) tersendiri dalam melakukan segala aktivitas pondok.

Dilihat dari segi pengontrolan/ controlling, setiap unit usaha yang ada pada Pondok Modern Darussalam Gontor melakukan evaluasi terhadap kegiatan yang telah diberlakukan setiap hari, mingguan, bulanan, bahkan setiap 3 bulan sekali. Seluruh staff/ asatidz melakukan totalitas kegiatan unit usaha dengan memegang penuh amanah, kepecayaan, serta niat ibadah dalam menjalankannya. Dengan demikian, proses pengontrolan (controlling) dapat diklasifikasikan pada kriteria sangat baik.

Secara keseluruhan, implementasi manajemen bisnis yang diberlakukan oleh Pondok Modern Darussalam Gontor tergolong baik. Hal tersebut dibuktikan dengan Keberhasilan unit usaha pesantren terhadap frekuensi peningkatan keuntungan (laba bersih) setiap tahunnya.

Dengan berjalannya pelaksanaan fungsi manajemen pada pelaksanaan kegiatan unit usaha di Pondok Modern Darussalam Gontor, maka hasil yang didapatkan adalah Mekanisme organisasi berjalan dengan baik; Mengetahui kendala dan permasalahan pada bagian unit usaha; Mencari solusi terhadap permasalahan yang ada; Adanya akuntabilitas dan transparansi keuangan antar unit usaha; Meminimalisir kegagalan dan mengotimalkan keberhasilan; Usaha ekonomi menjadi media pembelajaran dan pengalaman; Terciptanya kemandirian ekonomi di Pesantren;

\section{Karakteristik Bisnis Pondok Modern Darussalam Gontor Ponorogo}

Keberhasilan Pondok Modern Darussalam Gontor dalam mengelola unit usaha membentuk karakteristik tersendiri. Adapun karakteristik pengelolaan unit usaha Pondok Modern Darussalam Gontor adalah:

1) Perencanaan (planning) berbasis nilai Pondok;

2) Pengorganisasian (organizing) berbasis kaderisasi;

3) Kepemimpinan kolektif transformatif;

4) Total Quality Control.

Dalam proses implementasi, karakteristik pengelolaan tersebut 
membentuk karakteristik secara umum, yakni:

1) Pelaksanaan Kegiatan Unit Usaha Berbasis Learning By Doing;

2) Implementasi Prinsip Self Berdruing System;

3) Sentralisasi Keuangan Terpusat; serta

4) Terciptanya Keseimbangan Kesejahteraan Lahiriyah dan Batiniyah.

Keseluruhan karakteristik unit usaha pesantren tercermin pada pola manajemen berbasis nilai pondok. Visi dan Misi yang menjadi dasar pergerakan. Motto Pondok yang menjadi kekuatan dalam segala aktivitas. Panca Jiwa yang menjadi landasan jiwa seluruh penghuni pondok. Serta Panca jangka sebagai program pondok secara sustainable dan continue.

Sentralisasi keuangan yang berpusat pada bagian Administrasi pondok merupakan karakteristik yang membedakan manajemen unit usaha yang ada di pondok modern Darussalam Gontor jika dibandingkan dengan pengelolaan unit usaha pesantren yang ada di Indonesia.

\section{KARAKTERTISTIK BISNIS}

PONDOK MODERN DARUSSALAM GONTOR

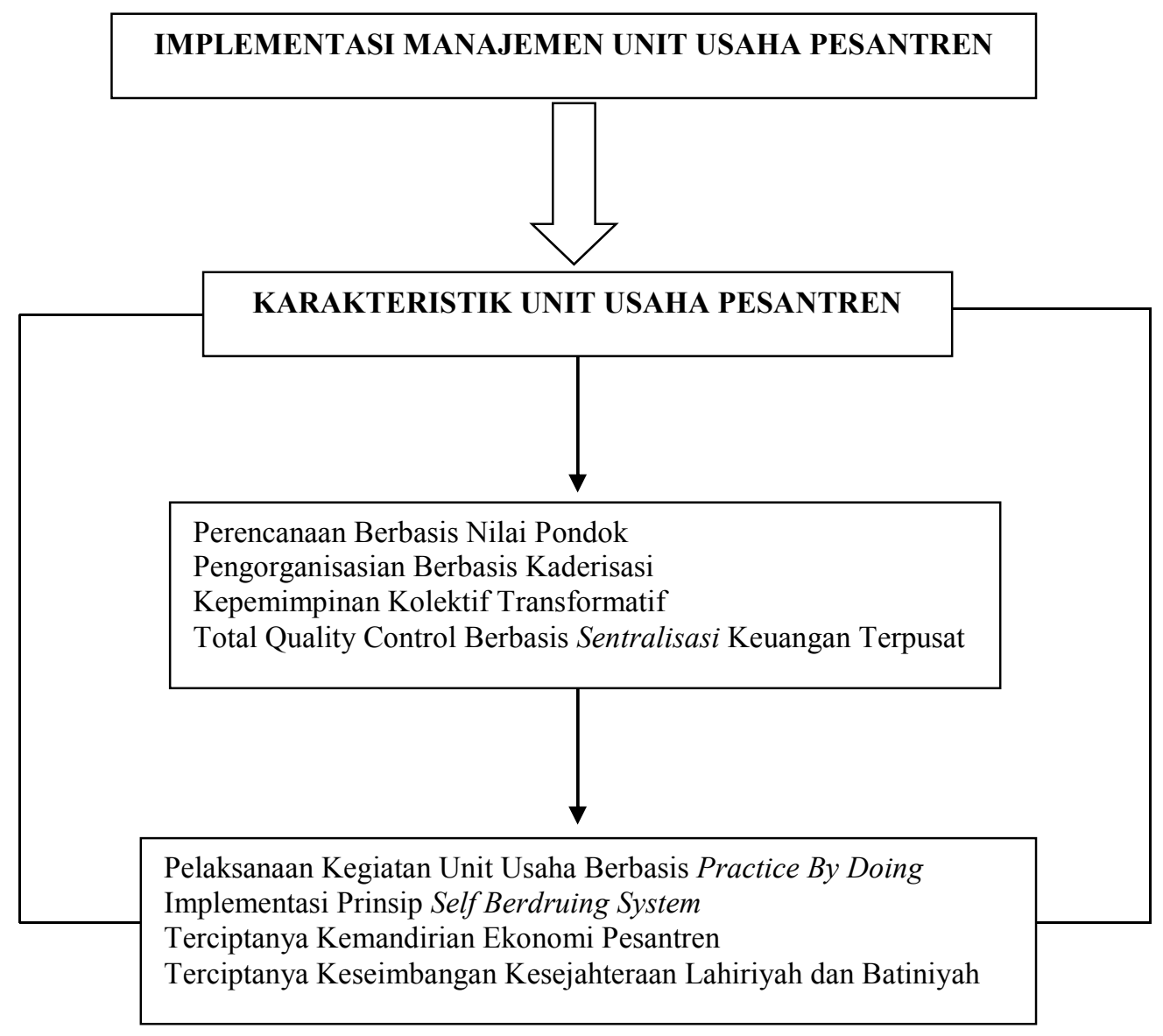

Kesimpulan

Secara keseluruhan, implementasi manajemen bisnis yang diberlakukan oleh Pondok Modern Darussalam Gontor tergolong baik. Hal tersebut dibuktikan dengan Keberhasilan unit usaha pesantren terhadap frekuensi peningkatan keuntungan (laba bersih) setiap tahunnya. Dengan berjalannya pelaksanaan fungsi manajemen pada pelaksanaan kegiatan unit usaha di Pondok Modern Darussalam Gontor, 
maka hasil yang didapatkan adalah Mekanisme organisasi berjalan dengan baik; Mengetahui kendala dan permasalahan pada bagian unit usaha; Mencari solusi terhadap permasalahan yang ada; Adanya akuntabilitas dan transparansi keuangan antar unit usaha; Meminimalisir kegagalan dan mengotimalkan keberhasilan; Usaha ekonomi menjadi media pembelajaran dan pengalaman; Terciptanya kemandirian ekonomi di Pesantren;

Keseluruhan karakteristik unit usaha pesantren tercermin pada pola manajemen berbasis nilai pondok. Visi dan Misi yang menjadi dasar pergerakan. Motto Pondok yang menjadi kekuatan dalam segala aktivitas. Panca Jiwa yang menjadi landasan jiwa seluruh penghuni pondok. Serta Panca jangka sebagai program pondok secara sustainable dan continue. Sentralisasi keuangan yang berpusat pada bagian Administrasi pondok merupakan karakteristik yang membedakan manajemen unit usaha yang ada di pondok modern Darussalam Gontor jika dibandingkan dengan pengelolaan unit usaha pesantren yang ada di Indonesia.

\section{DAFTAR PUSTAKA}

Abdullah, Ma'ruf, Manajemen Berbasis Syariah, Yogyakarta, Aswaja Pressindo, 2012.

Abdurrahman, Zen, Strategi Genius Marketing ala Rasulullah, Yogyakarta: Diva Press, 2011.

Amirullah, Haryadi, Muhammad sebagai Bisnisman Ulung, Jakarta: PT Elex Media Komputindo, 2011.

Azizah, Siti Nur, "Pengelolaan Unit Usaha Pesantren Berbasis Ekoproteksi (Studi Kasus Di Pondok Pesantren
Al-Ihya Ulumuddin, Cilacap)," Tesis, Program Pascasarjana UIN Sunan Kalijaga Yogyakarta, 2014.

Castles, Lance, Gontor Sebuah Catatan Lama, Ponorogo: Trimurti Gontor, 1991.

Chamidi, Nur, Marketing Syariah Sebagai Perangkat Dalam Menjalankan Bisnis Beretika Dan Trend Bisnis Dunia Global, dalam www.stainkediri.ac.id., 1 April 2015, pp. $1-23$.

Daniar, "Ekonomi Kemandirian Berbasis Koppontren," Jurnal Ekonomi Islam, Vol. 1, No. 2, Juli 2013, pp. 203216.

Effendi, Mochtar, Manajemen Suatu Pendekatan Berdasarkan Ajaran Islam, Jakarta: PT Bhratara Karya Aksara, 1986.

Ernie Tisnawati Sule dan Kurniawan Saefullah, Pengantar Manajemen, Jakarta: Kencana, 2005.

Faozan, Ahmad, "Pondok Pesantren dan Pemberdayaan Ekonomi," Jurnal Ibda', Vol. 4, No. 1, Tahun 2006, pp. $1-12$.

Faqih, dkk. Warta Dunia Pondok Modern Darussalam Gontor, Ponorogo: Pondok Modern Darussalam Gontor, 2012.

Fasa, Muhammad Iqbal, Peranan Koperasi Pondok Pesantren Dalam Meningkatkan Kemampuan Entrepreneur Santri, Skirpsi, IAIN Raden Intan Lampung, 2012.

Fauroni, Lukman, "Model Bisnis Berbasis Ukhuwah (Studi Kasus Pesantren 
Al-Ittifaq Kabupaten Bandung, ' Disertasi, Program Doktor UIN Sunan Kalijaga Yogyakarta, 2013.

Griffin, Manajemen: Jilid 1 Edisi 7, Jakarta: Erlangga, 2004.

Harjito, dkk, "Studi Potensi Ekonomi dan Kebutuhan Pondok Pesantren Se Karesidenan Kedu Jawa Tengah," Jurnal Fenomena, Vol. 6, No. 1, Maret 2008.

Hasibuan, Malayu, Manajemen: Dasar, Pengertian, dan Masalah, Bumi Aksara: Jakarta, 2001.

Hasyim, Muhammad, "Islamic Perception Of Business Ethics And The Impact Of Secular Thoughts On Islamic Business Ethics," International Journal of Academic Research In Business And Social Science, Vol. 2, No. 3, March 2012, pp. 98120

Indra, Hasbi, Pesantren dan Transformasi Sosial Study atas Pemikiran KH. Abdullah Syafe'I dalam Bidang Pendidikan Islam, Jakarta: Permadani, 2005.

Juhaya S. Praja dan Mukhlisin Muzarie, Pranata Ekonomi Islam: Wakaf, Jawa Barat: STAIC Press, 2009.

John R. Schermerhorn, Jr, Manajemen, Yogyakarta: Andi, 2000.

Karim, Adiwarman, Sejarah Pemikiran Ekonomi Islam, Jakarta: Raja Grafindo, 2004.

L. Daft, Richard, Era Baru Manajemen Jilid 1 Edisi 9, Jakarta: Salemba Empat, 2013.
Multitama, Islamic Buseness Strategy for Entrepreneurship Bagaimana menciptakan dan membangun usaha yang Islami, Jakarta: Zikrul Hakim, 2006.

Muttaqin, Rizal, "Peran Pondok Pesantren Terhadap Kemandirian Ekonomi Santri dan Pemberdayaan Ekonomi Masyarakat Sekitar," Tesis, Sekolah Pascasarjana Universitas Gajah Mada Yogyakarta, 2010.

Panitia Pekan Perkenalan Khhutbatul Arsy, Smart Book Pekan Perkenalan Khhutbatul Arsy, Pondok Modern Darussalam Gontor, 2013.

Qomar, Mujamil, Pesantren dari Transformasi Metodologi Menuju Demokratisasi Institusi. Jakarta: Erlangga, 2002.

Riawan Amin, dkk, Menggagas Manajemen Syariah: Teori dan Praktik The Celestial Management, Jakarta: Salemba Empat, 2010.

Rohmah, Lailatul, "The Entrepreneurship Management of The Female Pesantren Al-Mawaddah In Coper Jetis Ponorogo," International Journal Of Pesantren Studies, Vol. 3, No. 2, 2009, hlm. 187-201.

Slamet Widodo, "Agribisnis Pesantren Sebagai Upaya Pengembangan UMKM \& Kewirausahaan di Pedesaan," dalam Seminar Nasional Revitalisasi Peran UMKM dalam Pembangunan Melalui Penguatan Sektor Agroindustri, Universitas Sebelas Maret Surakarta, 23 November 2011. 
Soekarno K, Dasar-dasar Manajemen, Jakarta: Miswar, 1982.

Suhartini, "Problem Kelembagaan Pengembangan Ekonomi Pesantren," dalam Pustaka Pesantren (ed.), Manajemen Pesantren, Yogyakarta: LKIS, 2009.

Suharto, Ahmad, Profil Pondok Modern Darussalam Gontor, Ponorogo: Darussalam Press , 2011.

Sulthon Mayhud dan Khusnurdilo, Manajemen Pondok Pesantren, Jakarta: Diva Pustaka, 2004.

Supi, Surya, "Pemberdayaan Ekonomi Rakyat Berbasis Pesantren (Studi Untuk Mengembangkan Peran Pesantren Dalam Pemberdayaan Ekonomi Masyarakat Kabupaten Hulu Sungai Utara," Tesis, Program Pascasarjana Magister Administrasi Publik Universitas Gajah Mada Yogyakarta, 2009.

Sutatmi, dkk, "Program Pendidikan Wirausaha Berwawasan Gender Berbasis Jasa Boga Di Pesantren Salaf," Jurnal Ekonomi Dan Bisnis, Vol. 16, No.1, tahun 201l, hlm. 1-10.

Syamsi, Ibnu, Pokok-pokok Organisasi dan Manajemen, Jakarta: Rineka Cipta, 1988.

Tim Penyusun, Sejarah Balai Pendidikan Pondok Modern Gontor Indonesia dari Zaman Wali ke Zaman Tegalsari, Ponorogo: Gontor Pres, 1997.

Tim Penyusun, Biografi K.H. Imam Zarkasyi: Dari Gontor Merintis Pesantren Modern, Ponorogo: Gontor Press, 1996.
Tim Redaksi WARDUN 2008, Warta Dunia Pondok Modern Darussalam Gontor, Darussalan Press: Gontor, 2008.

Tim Redaksi WARDUN 2009, Warta Dunia Pondok Modern Darussalam Gontor, Darussalan Press: Gontor, 2009.

Tim Redaksi WARDUN 2012, Warta Dunia Pondok Modern Darussalam Gontor, Darussalan Press: Gontor, 2012.

Tim Redaksi WARDUN 2014, Warta Dunia Pondok Modern Darussalam Gontor, Darussalan Press: Gontor, 2014.

Veitzal, dkk, Islamic Business And Economics Ethics: Mengacu Pada Al-Qur'an dan Mengikuti Jejak Rasulullah SAW dalam Berbisnis, Keuangan, dan Ekonomi, Jakarta: Bumi Aksara, 2012.

Islamic Management: Meraih Sukses Melalui Praktik Manajemen Gaya Rasulullah Secara Istiqomah, Yogyakarta: BPFE, 2013.

W. Griffin, Ricky, Manajemen Jilid 1 Edisi 7"terj"oleh Gina Gania, Jakarta: Erlangga, 2004.

Yonita, Oci, Manajemen Bisnis Modern ala Nabi Muhammad, Jakarta Timur: AlMaghfiroh, 2012.

Yusuf dan Suwito, Model Pengembangan Ekonomi Pesantren, Purwokerto: STAIN Purwokerto Press, 2010. 
Zailani, Abdullah, Agama Pendidikan Islam dan Tanggung Jawab Sosial Pesantren, Yogyakarta: Pustaka Pelajar, 2008
Zarkasyi, Abdullah Syukri, Manajemen Pesantren Pengalaman Pondok Modern Gontor, Ponorogo: Trimurti Press. 2005. 